\title{
Propionic acid treated grain (oats) in the diet of horses
}

\author{
MARKKU T. SAASTAMOINEN
}

SaAstamoinen, M.T. 1994. Propionic acid treated grain (oats) in the diet of horses. Agricultural Science in Finland 3: 161-167. (Agricultural Research Centre of Finland, Equine Research, FIN-32100 Ypäjä, Finland.)

Use of oats treated with propionic acid in horse feeding was investigated in a 48 day feeding trial. Twenty horses were divided into a control and an experimental group. Horses in the control and experimental groups were fed with hay and dry or propionic acid treated oats, respectively, according to their energy requirements. The influence of the diet on health, faecal microflora, haemoglobin and haematocrit values, blood serum glucose concentrations, and weight change was investigated. The state of the health of all the horses was good throughout the trial. The functioning of the digestive tract of the horses was normal, since no symptoms of a declined health status of the digestive tract or harmfull effects on microflora due to propionic acid treated oats were observed. Also the haematology of the horses was unaffected by the diet. These data indicated that propionic acid treated grain can succesfully be included in rations for horses.

Key words: E.coli, equine, faecal microflora, nutrition

\section{Introduction}

The preserved feeds used during the indoor feeding period are often poor or insufficient in their hygienic quality (MeYer et al. 1986, KotimaA 1990, Coenen and KiEnzle 1992), mainly due to bad weather conditions during harvesting. This may lead to health problems such as respiratory diseases, colic, bacterial infections and botulism, as well as to reduced performance in many horses.

Cereals are the principal source of energy in the diet of hard-worked horses. Oats are the traditional and the most common grain in horse feeding in Northern Europe, but they often have a larger load of micro-organisms than other cereals (YLIMÄKI et al. 1979, KAMPHUES et al. 1991). For example, studies conducted in Germany showed that $20-60 \%$ of the samples investigated were contaminated (ZMIJA 1991, CoEnEN and KiEnZle 1992). This is partly due to, compared to other cereals, the special surface of oats and to the later harvesting period, which often means unfavourable weather conditions. The amount of fungi shows great variation annually depending on the climatic conditions during harvesting time (YLIMÄKI 1981).

Treatment of grain with propionic acid prevents the growth of bacteria in the feed, and propionic acid acts also as a mold inhibitor (JONES et al. 1974). Furthermore, moist grain is free from dust.

Although advantages due to propionic acid treatment of grain have been recognized, horse owners have questioned the safety, acceptability and feed value of acid treated grain for horses. No reports were found in the scientific literature of feeding propionic acid treated grain to horses, 
but FRAPE (1986) suggest that grain treated with propionic acid is only marginally suitable for feeding of horses owing partly to its acidity. However, hay (LAWRENCE et al. 1987, BATTLE et al. 1988) and silage (Peltonen 1986, AustBo 1990) preserved with organic acids has been reported to be readily consumed by horses and cause no apparent ill effects. It is also known that propionic acid exists normally in different regions of the digestive tract of the horse (KERN et al. 1974). Propionic acid treated grain have been reported to have same nutritional value for cows and pigs than untreated dry grain (CLARK et al. 1973, ENGLISH et al. 1973).

This feeding experiment was conducted to study the usability of propionic acid treated oats in horse feeding, and to determine their influence on health, haematology, faecal microflora and weight change of horses.

\section{Material and methods}

\section{Horses}

Twenty healthy Finnhorses ( 8 trotters and 12 riding horses) aged 4 to 8 years were divided into a control (C) and experimental (E) group, ten horses in each group. The groups were balanced for sex and age differences and the purpose of the horse (riding or trotting). The horses were exercised approximately $1 \frac{1}{2}$ hours per day (light or moderate work). The mean body weight of the horses was $525 \mathrm{~kg}$.

\section{Feeds and feeding}

The oats used in this experiment was harvested in early October in south-western part of Finland (latitude $61^{\circ}$ ). After harvesting at the moisture of $30 \%$, part of the oats was treated with a commercial propionic acid presevative (Propcorn; propionate concentration $97.5 \%$, Brittish Petroleum). The propionic acid concentration of the treated oats was $0.62 \%$ in the feed (on a weight basis).

The control oats from the same crop was dried
Table 1. Composition and feeding values of the feeds.

\begin{tabular}{lrrr}
\hline & Hay & $\begin{array}{c}\text { Acid treated } \\
\text { oats }\end{array}$ & Dry oats \\
\hline $\begin{array}{l}\text { Dry matter \% } \\
\text { Contents of dry }\end{array}$ & 85.9 & 70.1 & 86.6 \\
$\begin{array}{l}\text { matter (\%) } \\
\quad \text { Crude protein }\end{array}$ & 7.5 & 14.3 & 14.3 \\
$\quad$ Crude fat & 2.2 & 6.1 & 5.9 \\
$\quad$ Crude fibre & 34.5 & 9.9 & 9.1 \\
$\quad$ Ash & 5.5 & 3.3 & 3.3 \\
$\begin{array}{l}\text { Feed values } \\
\text { kg/FU }\end{array}$ & & & \\
$\quad \begin{array}{l}\text { ME MJ/kg DM } \\
\text { DCP g/FFU }\end{array}$ & 2.0 & 1.42 & 1.15 \\
pH & 9.1 & 12.0 & 12.1 \\
Concentr. of \\
propionic acid \\
(\%)
\end{tabular}

$\mathrm{FU}=$ feed unit DCP $=$ digestible crude protein $; \mathrm{ME}=$ metabolizable energy

to the moisture content of 13 to $14 \%$. The both oats were rolled before feeding.

Feed samples were collected daily and the feeds were analyzed by standard methods. The FU (feeding unit) and DCP (digestible crude protein) values were calculated according to Finnish feeding tables (SALO et al. 1990), and ME (metabolisable energy) values according to MAFF (1975). The feeding values and composition of the feeds are presented in Table 1.

Palatability of the propionic acid treated oats was tested with five horses prior to the experiment, and the horses were observed to ingest the feed with good appetite. Change from dried to treated oats in the E-group was made during seven days.

The horses were fed individually three times per day throughout the 48-day feeding trial, according to their size and amount of daily exercise. Horses in both groups were given $6 \mathrm{~kg}$ longstem timothy-dominated hay (cut at full-bloom stage), 2.3-4.4 kg oats (dried oats in C-group and propionic acid treated oats in E-group), and $300 \mathrm{~g}$ wheat bran per day. The forage-to-concen- 
trate ratio of the diet for both groups was about 50:50 on an energy basis.

The diets of both groups were supplemented with a mineral concentrate, and the horses in the experimental group were given a supplementation of synthetic form of vitamin E $300 \mathrm{mg}$ per day. Each horse had an automatic drinking bowl.

Average energy and protein intakes were 6.1 FU (85.6 MJ ME) and $578 \mathrm{~g} \mathrm{DCP}$ per day. The dry matter intake was $9.02 \mathrm{~kg}$ per day.

\section{Blood sampling and chemical analysis}

Blood samples (5 samples per horse) were collected at the beginning of the trial and at twoweek intervals during it, from the jugular vein into evacuated blood collection tubes for haemoglobin $(\mathrm{Hb})$, haematocrit $(\mathrm{Hc}$, packed cell volume) and serum glucose determinations.

$\mathrm{Hb}$ and $\mathrm{Hc}$ were determined for the purpose to indicate possible changes in the health status of the horses (SNOw and Vogel 1987). Hb (g/l) was determined by cyanmethemoglobin and $\mathrm{Hc}$ by microcapillary methods.

Blood serum glucose $(\mathrm{mmol} / \mathrm{l})$ was determined photometrically by the glucose-dehydrogenase method (BorgmeYer 1974, HeNRY 1974) with Gilford Stasar-spectophotometry.

\section{Faecal sampling and counting of bacteria}

Faecal samples were also collected at two-week intervals from the rectum to investigate the faecal microflora, as an indicator of the microbial status of the digestive tract.

In the faecal samples, the number of colonies $\left(10^{3} / \mathrm{g}\right)$ of E.coli and other coliform bacteria were counted (MÅNSSON 1957), and molds were determined visually after cultivating $5 \mathrm{~g}$ of rectal contents on EMB-agar at $37^{\circ} \mathrm{C}$. The incubation time was 24 hours.

Counting continued up to $100 \times 10^{3} / \mathrm{g}$. Larger numbers of colonies are considered to indicate a very good status and balance of intestinal microflora (Yhtyneet Laboratoriot 1985). In addition, the range of faecal streptococci was counted.

\section{Weighing the horses}

The weight of the horses was measured at twoweek intervals. Furthermore, the state of the health of the horses was observed regularly.

\section{Statistical methods}

The differences between the feeding groups in the distribution among the classes of the number of faecal E. coli and coliform bacteria colonies $\left(<50 * 10^{3}, 50-99 * 10^{3}\right.$ and $\left.>100 * 10^{3}\right)$ was tested by the $\chi^{2}$-test.

The data consisting of blood parameters and body weights were subjected to an analysis of variance. In addition to the feeding group, the statistical model included the following factors: sex, age and class of purpose (riding or trotting) of the horse. The initial values of the studied parameters were included in the statistical model as covariates.

\section{Results and discussion}

The horses in both groups had good appetites throughout the trial and they consumed all the feeds offered. The state of the health of all the horses during the course of the trial was good. The $\mathrm{Hb}$, $\mathrm{Hc}$ and $\mathrm{MCHC}(\mathrm{Hb} / \mathrm{Hc})$ values observed (Table 2$)$ were not statistically significantly affected by the diet and agreed with values reported for healthy horses in literature (KossILA et al. 1972, KÄÄNTEE 1977, Pösö et al. 1983). However, the $\mathrm{Hb}$ and $\mathrm{Hc}$ values in the E-group increased slightly during the study period, and decreased first and increased thereafter in the C-group.

The functioning of the digestive tract of the horses was normal, since no diarrhoea or other symptoms of a declined health status of the digestive tract or harmfull effects on microflora were observed.

Faecal E.coli and other coliform bacteria were used as an indicator of the microbial status and health of the digestive tract. A lactate-fermenting strain of E.coli is present throughout the horse's digestive tract (ALEXANDER and DAVIS 1963), but 
Table 2. Blood parameters of the horses in the different feeding groups (LS-means and SE).

\begin{tabular}{lcc}
\hline & \multicolumn{2}{c}{ Group } \\
\cline { 2 - 3 } & $\begin{array}{c}\text { Control }(\mathrm{C}) \\
\mathrm{n}=10\end{array}$ & $\begin{array}{c}\text { Experimental }(\mathrm{E}) \\
\mathrm{n}=10\end{array}$ \\
\hline Haemoglobin $(\mathrm{g} / \mathrm{l})$ & & \\
$\quad$ Initial & $124.4 \pm 3.1$ & $123.5 \pm 3.4$ \\
Final & $123.9 \pm 2.8$ & $129.1 \pm 2.5$ \\
Average & $122.5 \pm 1.9$ & $125.4 \pm 1.7$ \\
Haematocrit $(\%)$ & & \\
Initial & $34.4 \pm 0.7$ & $36.4 \pm 0.9$ \\
Final & $33.7 \pm 0.7$ & $35.4 \pm 0.6$ \\
Average & $33.7 \pm 0.5$ & $34.7 \pm 0.5$ \\
MCHC & & \\
Initial & $36.2 \pm 0.5$ & $36.4 \pm 0.5$ \\
Final & $36.5 \pm 0.2$ & $36.3 \pm 0.2$ \\
Average & $36.2 \pm 0.2$ & $36.3 \pm 0.2$ \\
Glucose & & \\
Initial & $3.84 \pm 0.16$ & $4.04 \pm 0.15$ \\
Final & $3.81 \pm 0.19$ & $3.86 \pm 0.17$ \\
Average & $3.71 \pm 0.10$ & $3.95 \pm 0.10$ \\
\hline
\end{tabular}

Averages are means of the all values ( $\mathrm{n}=4$ for each horse) during the experiment

$\mathrm{MCHC}=$ mean cell haemoglobin content

E.coli composed only a small percentage of the total viable bacteria in different gut regions (KERN et al. 1974).

No statistically significant differences between the groups in the distribution of horses among the classes by the number of E.coli and coliform bacteria could be detected. There was, however, a considerable variation in the number of the colonies of E.coli and other coliforms between the individuals in both groups, and also between the samples from an individual animal. The number of colonies increased in both groups from the beginning to the end of the trial.

Streptococci and molds were found in the faeces of all the horses. The number of samples occupied by molds during the trial was 12 and 23 in the E-group and C-group horses, respectively. Consequently, the mold content of the experimental diet might be lower than that of the control diet.
The conclusions based on the faecal microflora were supported by MÅNSSON (1957) who reported a close connection between the state of health of the host animal and the intestinal and faecal microflora. In addition, it has been reported that volatile fatty acids (VFA) produced in bovine rumen may inhibit growth of E.coli and other coliform bacteria at pH lower than 7.0 (WoLIN 1969), which is also out of the optimun $\mathrm{pH}$ area in the small intestine and cecum of the horse (MEYER 1992).

Nurmio et al. (1973) found coli bacteria, faecal streptococci, lactobasilli, chlostridia, molds and yeasts in the faeces of horses with normal digestive functions. High counts of coliforms and low counts of molds have been found in the faeces of healthy horses (WIERUP and DiPIETRO 1981).

Skin changes - which were not observed in this study - are also indicators of the poor status of intestinal microflora (MÅNSSON 1957).

Propionic acid normally exists in all gut regions of horses, the highest concentrations found in cecum and colon (HINTZ et al. 1971, KERN et al. 1973). About $50 \%$ of the acid producing bacteria in the large intestine produces propionic acid (KERN et al. 1973). The equine large intestine may approach the ruminant's forestomach in its highly absorption of VFA (ARGENZIO et al. 1974).

The propionate production has been reported to amount $19.6-34.0$ and $146-195 \mathrm{mg} / \mathrm{h}$ per $\mathrm{kg}$ body weight in the cecum and colon in ponies fed with hay or hay and wheat bran (FoRD and SIMMONS 1985, SIMMONS and FORD 1991). If that data are extrapolated to the average horse of this study (body weight $525 \mathrm{~kg}$ ), as much as 252 to $428 \mathrm{~g}$, and 1839 to $2457 \mathrm{~g}$ of propionate would be produced daily in the cecum and colon, respectively. Thus, the propionate derived from the treated oats ( 15 to $27 \mathrm{~g}$ ) causes only a minimum increase in the total propionate concentration in the gut of the horse.

Because propionate is also produced in stomach and small intestine and absorbed in the small intestine (KERN et al. 1974), it is possible that also the propionate derived from the acid treated oats was absorbed in the small intestine before 
reaching the large intestine. Further, the buffering mechanism inhibits the $\mathrm{pH}$ value in the gut to decline too low (MEYER 1992). In ruminants, propionic acid treated grain decreased the ratio between acetate and propionate in the rumen (CLARK et al. 1973).

There were no statistical differences in the blood glucose concentrations between the groups (Table 2). The present serum glucose concentrations were within the normal ranges reported for Finnhorses (Pösö et al. 1983). Healthy horses maintain a blood glucose concentration within certain defined limits (FRAPE 1986).

Blood glucose concentration is an expression of a dynamic balance between glycogen breakdown and synthesis, as well as the production of glucose from other sources, e.g. propionate in the large intestine. According to FORD and SIMMONS (1985) most of the blood glucose derived from the digestion of starch and low molecular carbohydrates in the small intestine, and 7\% of the total glucose production was derived from propionate produced in the cecum. In their other study (SIMMONS and FORD 1991) 50 and $61 \%$ of the blood glucose was synthesized from propionate produced in the colon in ponies fed hay or hay and wheat bran diets, respectively.

HINTZ et al. (1971) found no increased plasma glucose concentrations although propionate production increased in cecum. ArgenZIO and HINTZ (1970) reported that infusion of propionate into cecum increased plasma glucose in fasted ponies but not in fed ponies. In the present study the amount of propionate derived from the treated oats was so small that increase of blood glucose concentration was not expectable.
The body weight of the horses in both groups decreased about $1.8 \%$ during the course of the trial. The decline in the body weight might be due to more controlled and accurate feeding during the trial compared to the feeding prior to the trial.

Propionic acid treated grain can be fed to horses safely, which is supported by LAWRENCE et al. (1987) and BATTLE et al. (1988), who fed propionate treated hay to horses. High moisture grain may have application for horses with chronic respiratory problems and that are exacerbated by dry or dusty feed.

When moist grain is fed by weight or volume, the higher water content should be taken into account. In addition, a vitamin E supplementation at a level of $30 \mathrm{mg} / \mathrm{kg}$ feed is recommended (FRAPE 1986), because propionic acid treatment of moist grain resulted in distruction of vitamin E (RICE et al. 1985). Further, metabolism of propionate requires vitamin $\mathrm{B}_{12}$, the lack of which causes an accumulation of propionate, depressing appetate (FRAPE 1986). Thus, also dietary vi$\operatorname{tamin} B_{12}$ requirement may increase if large amounts of propionic acid treated grain is fed.

\section{Conclusions}

No palatability problems, harmful effects on the digestive tract function or other health disturbances associated with feeding of propionic acid treated oats, were noted in this 48-day feeding trial. Thus, these data indicated that propionic acid treated grain can succesfully be included in rations for horses.

\section{References}

Alexander, F. \& Davis, M.E. 1963. Production and fermentation of lactate by bacteria in the alimentary canal of the horse and pig. Journal of Comparative Pathology 73: 1-8.

Argenzio, R.A. \& HinTZ, H.F. 1970. Glucose tolerance and effect of volatile fatty acid on plasma glucose concentration in ponies. Journal of Animimal Science 30: 514-518.
-, Southworth, M. \& Stevens, C.E. 1974. Sites of organic acid production and absorption in the equine gastrointestinal tract. American Journal of Physiology 226: 1043-1050.

AustBo, D. 1990. Hay and silage of the same crop fed to horses. Paper. 41st Annual Meeting of European Association for Animal Production. 5 p.

Battle, G.H., Jackson, S.G. \& BAKER, J.P. 1988. Accept- 
ability and digestability of preservative-treated hay by horses. Nutrition Report International 37: 83-89.

BORGMEYER, H.U. 1974. Methoden der enzymatischen Analyse. Vol. 1: 3rd ed., 175 p. Verlag Chemie.

Clark, J.H., Frogish, R.A. Harsbergek, K.E. \& DerRING, R.G. 1973. Feeding value of dry corn, ensiled high moisture corn and propionic acid treated high moisture corn fed with hay or haylage for lactating dairy cows. Journal of Dairy Science 86: 1331-1339.

Coenen, M. \& Kienzle, E. 1992. Beobachtungen zur hygienischen Beschaffenheit von Futtermitteln für Pferde in der tierärztlichen Ernährungsberatung. Pferdeheilkunde, Sonderausgabe 8: 209-212.

ENGLish, P.R., TopPS, J.H. \& DEMPSTER, D.G. 1973. Moist barley preserved with propionic acid in the diet of the growing pig. Animal Production 17: 75-83.

FORD, J.H. \& Simmons, H.A. 1985. Gluconeogenesis from caecal propionate in the horse. British Journal of $\mathrm{Nu}$ trition 53: 55-60.

FRAPE, D. 1986. Equine nutrition and feeding. 373 p. Longman, Essex.

HenRY, R.J.M. 1974. Clinical Chemistry. 2nd ed. Harper \& Row, New York. p. 1301-1302.

HinTZ, H.F., ARgenzio, R.A. \& SCHRYVER, H.F. 1971. Digestion coefficients, blood glucose levels and molar percentage of volatile acids in intestinal fluid of ponies fed varying forage-grain ratios. Journal of Animal Science 33: 992-995.

Jones, G.M., Mowat, D.N., Elliot, J.I. \& Moran, E.T. 1974. Organic acid preservation of high moisture corn and other grains and the nutritional value: A review. Canadian Journal of Animal Science 54: 499-517.

KÄÄNTEE, E. 1977. Hematological values of the Finnish warmblooded trotters in racing condition. Journal of the Scientific Agricultural Society of Finland 49: 167175.

Kamphues, J., Fimmen, H., Küstermann, S. \& Meyer, H. 1991. Lipopolysaccharides in feedstuffs for horses. Equine Nutrition Pysiology Symposium 11: 36-41.

Kern, D.L., Slyter, L.L., Weawer, J.M., Leffel, E.C. \& Samuelson, G. 1973. Pony cecum vs. steer rumen: The effect of oats and hay on microbial ecosystem. Journal of Animal Science 37: 463-469.

-, Slyter, L.L., Weawer, J.M., Leffel, E.C. \& Oltuen; R.R. 1974. Ponies vs. steers: Microbial and chemical characteristics of intestinal ingesta. Journal of Animal Science 38: 559-563.

Kossila, V., TanhuanpäÄ, E., Virtanen, E. \& Luoma, E. 1972. Blood levels of hemoglobin, glucose, cholesterol, minerals and trace elements in saddle horses. I. Differences due to age and maintenance. Journal of the Scientific Agricultural Society of Finland 44: 249257.

KotimaA, M. 1990. Spore exposure arising from stored hay, grain and straw. Journal of Agricultural Science in Finland 62: 285-291.

LAWrence, L.M., MOORE, K.J., Hintz, H.F., Jaster, E.H. \& Wischover, L. 1987. Acceptability of alfalfa hay treated with an organic acid preservative for horses. Canadian Journal of Animal Science 67: 217-220.

MAFF 1975. Energy allowances and feeding systems for ruminants. Ministry of Agriculture, Fisheries and Food (Maff). Technical Bulletin 33.9 p. London.

MÅnsson, I. 1957. The intestinal flora in horses with certain skin changes. Acta Pathologica et Microbiologica Scandinavica, Supplementum 119. 102 p.

MeYer, H. 1992. Pferdefütterung. 223 p. Paul Parey, Berlin.

-, Heckötter, E., Merkt, M. Bernoth, E.-M., Kienzle, E. \& Kamphues, J. 1986. Aktuelle Probleme aus der tierärztlichen Fütterungsberatung. 6. Mitteilung: Schadensfälle beim Pferd durch Futtermittel. Deutsche tierärztliche Wochenschrift. 93: 486-490.

Nurmio, P., KoIranen, L. \& TupamäKI, A. 1973. The faecal microflora of horses. (In Finnish - English summary). Suomen eläinlääkärilehti 79: 668-681.

Peltonen, T. 1986. Nitrogen level and allowances in pregnancy and lactation. 2. The value of silage in horse feeding. Paper. 37th Annual Meeting of European Association for Animal Production. 10 p.

Pösö, A.R., Soveri, T., \& OKSANEN, H.E. 1983. The effect of exercise on blood parameters in Standardbred and Finnish-bred horses. Acta Veterinaria Scandinavica 24: 170-184.

Rice, D.A., Blanchflower, W.J. \& McMurray, C.H. 1985. The effects of moisture, propionic acid, sodium hydroxide and anaerobiasis on the stability of vitamin E in stored barley. Journal of agricultural Science, Cambridge. 105: 15-19.

SAlo, M.-L., TuORI, M. \& KIISKINEN, T. 1990. Rehutaulukot ja ruokintanormit. 70 p. Helsinki.

Simmons, H.A. \& FORD, E.J.H. 1991. Gluconeogenesis from propionate produced in the colon of the horse. British veterinary Journal 147: 340-345.

SNOw, D.H. \& VoGEL, C.J. 1987. Equine fitness. The care and training of the athletic horse. 271 p. Longman, London.

Wierup, M. \& DiPietro, J.A. 1981. Bacteriologic examination of equine fecal flora as a diagnostic tool for equine intestinal clostridiosis. American Journal of Veterinary Research 42: 2167-2169.

Wolin, M.J. 1969. Volatile fatty acids and the inhibition of Escherichia coli growth by rumen fluid. Applied Microbiology 17: 83-87.

Yhtyneet Laboratoriot 1985. Hevosen laboratoriotutkimukset. 48 p. Yhtyneet Laboratoriot Oy. Helsinki.

YLIMÄKI, A. 1981. The mycoflora of cereal seeds and some feedstuffs. Annales Agriculturae Fenniae 20: 74-88.

-, Koponen, H., HintikKa, E.L., Nummi, M., NikU-PAAvola, M.L., IluS, T. \& ENARI, T.M. 1979. Mycoflora and occrrence of Fusarium toxins in Finnish grain. Technical Research Centre of Finland, Publ. 21. 28 p.

ZmiJA, G. 1991. Fütterungpraxis bei Galopp- und Trabrennpferden. Doctorial Thesis. Hannover. 73 p.

Manuscript received February 1994 


\title{
SELOSTUS
}

\section{Propionihapolla säilötyn kauran soveltuvuus hevosen ruokintaan}

\author{
MARKKU SAASTAMOINEN
}

\author{
Maatalouden tutkimuskeskus
}

Propionihapolla käsitellyn kauran soveltuvuutta hevosten ruokintaan tutkittiin 20 täysikasvuisella hevosella 48 päiväă kestäneessä kokeessa. Hevoset jaettiin tasan koe- ja kontrolliryhmiin, joista koeryhmälle annettiin viljaväkirehuna propionihapolla säilöttyä ja vertailuryhmälle kuivattua kauraa ravinnontarvetta vastaavasti. Tutkimuksessa selvitet- tiin ruokinnan vaikutusta hevosten terveyteen, veriarvoihin, painon muutokseen ja sonnan mikrobistoon.

Hevosten terveys pysyi kokeen ajan hyvänä, eikä hevosten ruoansulatuskanavan toiminnassa havaittu ruokinnasta johtuvia häiriöitä. Tulosten mukaan propionihapolla săilöttyă viljaa voidaan syöttăả turvallisesti hevosille. 